LUBLIN STUDIES IN MODERN LANGUAGES AND

LITERATURE 41(1), 2017, HTTP://WWW.LSMLL.UMCS.LUBLIN.PL, HTTP://LSMLL.JOURNALS.UMCS.PL

\author{
Serkan Ertin \\ Kocaeli University \\ Kocaeli, Turkey \\ Özlem Türe Abacı \\ Çanakkale 18 Mart University \\ Çanakkale, Turkey
}

\title{
The Magic Toyshop as Nucleus of Desire: A Lacanian Analysis
}

\begin{abstract}
The Magic Toyshop (1967), Angela Carter's second novel, is the story of a young middle-class English girl -Melanie, who with her brother and sister has to move to London and live with her uncle after the death of her parents in an accident. Uncle Philips functions as the primordial father in the household and does not tolerate any digression or transgression from the Law. This paper aims to offer a Lacanian analysis of The Magic Toyshop by focusing on the major polarity that stands out in the novel around which all the narrative is structured: Desire and Law.

Keywords: The Magic Toyshop; Angela Carter; Lacan
\end{abstract}

The Magic Toyshop ${ }^{1}$ (1967), Angela Carter's second novel, is the story of a young middle-class English girl - Melanie, who with her brother and sister has to move to London and live with her uncle after

\footnotetext{
${ }^{1}$ The Magic Toyshop is referred to as MT in brackets.
} 
the death of her parents in an accident. The story bears some characteristics of fairy tale narrative and through the narrative it reveals the construction and the reification of the Woman and the Man in the symbolic order. Melanie's uncle, Philip, who makes toys and puppets, treats all the characters in his household as if they were simple marionettes. He tries to function in the household as the primordial father and does not tolerate any digression or transgression. As a result of the oppression exerted upon themselves, the characters in the toyshop suffer from excessive levels of anxiety and guilt since they are torn between "Desire and Law" (Mellard 1991: 31). Desire and Law stand out in the novel as the major polarity around which all the narrative is structured.

Oedipus complex "is the nucleus of desire, repression and sexual identity. It is the point at which we are produced and constituted as subjects" (Sarup 1992: 5). It represents the beginnings of super ego, morality, conscience, law, and authority. It is "the final step in the process by which the normative subject is articulated and full symbolization is achieved. The Oedipal realisation makes the subject capable of seeing itself in a formal or structural relation to others and to objects" (Mellard 1991: 28). At the beginning of the novel, Melanie is already within the Symbolic. Her stealing Jonathon's books and selling them to buy a set of false eyelashes indicate that she tries to reestablish the Imaginary within the Symbolic. She is certainly aware of the male gaze and thus tries to relaunch her ideal ego. However, entering the Symbolic will hurt her, just like "the false eyelashes [which] made her weep painful tears" (MT 2006: 5).

The aim of the subject's Desire is to fuse once again with the Imaginary double who is first the mother, but who then becomes (in images linking to objets $a$ ) the displaced representation of the (m)other found in the interaction between the ego and the other (Mellard 1991: 31). Likewise, Melanie desires to be the surrogate Mother in her household, but she strives to achieve it in indirect ways, such as using her clothes or perfumes. For instance, once she "dabbed stale Chanel behind her ears and at once smelled so like her mother that she glanced at herself in the mirror to make sure she was still 
Melanie" (MT 2006: 14). This is obviously another attempt to reestablish the Imaginary in the Symbolic and Melanie still misrecognises, or intentionally tries to misrecognise, herself. According to Lacan, the central function of the ego is misrecognition (méconnaissance). During the mirror phase, when the infant cannot master its own body, imagines itself as a coherent and self-governing entity (Sarup 1992: 64). The child sees his image in the mirror, but the reflection is reversed and what the infant sees can never be himself/herself. Melanie, though not an infant any longer, still has the illusion of autonomy and feels that she has reached her peak, when she is only fifteen. She wants to relapse to the pre-verbal stage, but once castrated, a subject can never get out of the Symbolic.

The first garden scene is the metaphoric narrative of Melanie's castration process. Melanie is fond of wearing her mother's dresses and make-up. She occasionally walks into her parents' bedroom and tries to imagine how they make love. She unconsciously desires to be the Mother and possess the Father. One day, when her parents are away, she wears her mother's wedding dress; it feels cold. Walking in the garden in her mother's wedding dress, she finds the dress too big for herself:

The loneliness seized her by the throat and suddenly she could not bear it. She panicked. She was lost in this loneliness and terror crashed into the garden, and she was defenceless.... Branches, menacing, tore her hair and thrashed her face.

The grass wove itself into ankle-turning traps for her feet. The garden turned against Melanie when she became afraid of it. (MT 2006: 18)

She wanted to go back home, but the door was shut and she was locked out. Besides, she had cut her feet and was bleeding. The garden scene turns out to be her first awareness of the impossibility of becoming the Mother and her first repression.

Although Melanie's father is central to her inner conflicts and to the escalating tension between her and her mother, the father is never there physically - or textually in the narrative. The only thing known is that he is on a lecture tour abroad and very early in the book he dies in an accident with his wife. Sarup asserts that "desire persists as an effect of primordial absence" (1992: 68). Thus, the absence of 
Melanie's father fuels her desire. Desire is for something the subject lacks and is therefore insatiable, unlike a need or a demand. An example for Melanie's unconscious desire is the scene depicting the night she could not sleep: "It was late in the summer and the red, swollen moon winked in the apple tree and kept her awake. The bed was hot. She itched. She turned and twisted" (MT 2006: 9). The language used in the portrayal is highly symbolic and it has sexual allusions. Melanie tosses and turns in her hot bed, yet she does not know why. This is the very nature of desire; it is outside the subject and out of reach. Carter herself indicates that Melanie "is filled with [desire]. And that gives her power" (qtd in Gamble 1997: 70).

The sense of gap, lack, or absence is of great significance in the configuration of the subject according to Lacan. Just as in the case of Freud's grandchild, making the absence of his mother present to itself through 'fort-da' game, the real objects can be replaced by another object; thus, the symbol manifests itself first as the murder of the thing (Mellard 1991: 15).

[Melanie] used the net curtain as raw material for a series of nightgowns suitable for her wedding night which she designed upon herself. She gift-wrapped herself for a phantom bridegroom taking a shower and cleaning his teeth in an extradimensional bathroom-of-the-future in honeymoon Cannes. Or Venice. Or Miami Beach.... She could almost feel his breath on her cheek. (MT 2006: 2)

She creates the imaginary phantom in the absence of any experience with a boyfriend. However, she makes the absence of a boyfriend present to herself and it is so lifelike that she almost feels his breath on her cheek. Mrs. Rundle is very similar to Melanie in that respect. For her, the mediation and presence of the actual object is not required:

[Mrs. Rundle] adopted the married form [Mrs.] by deed poll on her fiftieth birthday as her present to herself.... She had always wanted to be married.... She would sit, sometimes, in her warm fireside chair, at the private time when the children were all in bed, dreamily inventing the habits and behaviour of the husband she had never enjoyed until his very face formed wispily in the steam from her bed-time cup of tea and she greeted him familiarly.” (MT 2006:3) 
In the Hegelian phenomenological idea the word is a death, a murder of a thing. Things are more present in a word, in its concept, than in its immediate physical reality (Sarup 1992: 57). For Mrs. Rundle it was not necessary to get married in order to be 'Mrs.' nor did she need to have a man to accompany her while drinking her bed-time tea.

In her own house Melanie desperately endeavours to reconstruct the pre-verbal register and because of that although she is in the Symbolic, her configuration in the Symbolic and submission to the Law-of-the-Father are problematic. In her case, the cognitive changes occur only after she commences living with her uncle. Her uncle Philip, a primordial father figure, is an oppressor and loves making his presence and authority felt everywhere in the house and in his toyshop. Melanie "saw her uncle only at mealtimes but his presence, brooding and oppressive, filled the house. She walked warily as if his colourless eyes were judging and assessing her all the time" (MT 2006: 92). The revitalisation of the Oedipus complex is constituted even if Philip is not in the house or shop; the Father is only a function (Sarup 1992: 100). Philip's wife Margaret, struck dumb upon her marriage to Philip, does not talk but writes to communicate. Language, the verbal register, alienates the subject while configuring and Margaret overtly resists this self-alienation. Preferring to write instead of speaking reverses the traditional Western hierarchy; speaking associated with 'Presence', whereas writing refers to 'Absence'. She also rejects the male gaze by not trying to fix herself up. With her surrogate mother and father figures, Melanie faces the Oedipal pattern once again, alongside with some differences though. This time in the room where Melanie lives there is no mirror and she does not look in a mirror for a long while. Her imagos through which she has defined herself have disappeared and she has changed. She is now a perfect castrated young girl and she has gained an awareness of her loneliness: "She felt lonely and chilled.... Now she was entirely alone, brother and sister both lost to her, Jonathon upstairs, Victoria downstairs and Melanie treading the dangerous route between them, connected to neither. 'If only' she thought, 'I wasn't so young and inexperienced and dependent'" (MT 2006: 82). What makes Melanie 
submit herself completely to the Symbolic is the revival of the oedipal pattern in her new house. As Mellard states, "the true register of the Symbolic is firmly laid in place by the cognitive changes that occur in the introjection of the law of Oedipus" (1991: 16).

Melanie's middle-class comfort of her childhood is shattered in Uncle Philip's house. She learns to repress her desire by being trained in how to read the socio-symbolic codes in the magic toyshop with the help of Finn and Aunt Margaret. The first thing she must learn is the dress code. Finn notices that she is wearing trousers which must be changed into a skirt because Uncle Philip "can't abide woman in trousers. He won't have a woman in the shop if she's got trousers on her" (MT 2006: 62). She is forbidden to wear make-up and should adopt the profile of the silent woman, as Finn says, "only speak when you're spoken to. He likes, you know, silent women" (MT 2006: 63). The space is also gender-marked in the toyshop, as women are allowed to the spaces of production such as the workshop only with permission. Melanie, as a naïve reader of space governed by the Law, tries to interpret how the power is distributed within the rooms of the house. She sees an image of herself at one end of the workshop, "[1]ying face-downwards in a tangle of strings was a puppet fully five feet high, a sylphide in a fountain of white tulle, fallen flat down as if someone had got tired of her in the middle of playing with her, dropped her and wandered off" (MT 2006: 67). She soon learns how the theatre-parlour and puppet-show are important for Uncle Philip. In one of his regular performances, the household is prepared with great care, "spruce and clean as for going to church," even the dog follows them "with the air of a dog doing its duty" (MT 2006: 126). Aunt Margaret helps Melanie to interpret Philip's expectations during the show; she begins to clap energetically "nudging Melanie to join in with her." Margaret protects the children by introducing them to the correct behaviour which will be accepted by the Law. She silences Victoria and Jonathon by hastily jamming a toffee into their mouths and warning Melanie to "look as if [she's] enjoying it, for [her] sake and for Finn's" (MT 2006: 128). Melanie submits to the Uncle's will, including the inscription of her body and sexuality. She is transformed 
into a passive object with the enactment of oedipal law that protects the male-oriented social order.

In the new household, the new source of anxiety and guilt turns out to be Melanie's desire for Finn, Margaret's brother, and the Law of Philip. During the rehearsal of Leda and the Swan, Uncle Philip's show starring Melanie and Finn, Finn reluctantly puts his hand on Melanie's right breast, and Melanie waits tensely for it to happen. However, Finn runs away and locks himself into the cupboard. Melanie "still felt his five fingertips, five red cinders, burning on her breast. But he was gone. She felt cold and ill" (MT 2006: 150). Melanie is torn between the forbidding Law and her Desire. In the same scene, Melanie is forced by Uncle Philip to take the part of Leda, upon whom he performs a virtual rape, projecting his incestuous desires for her. Early in the novel, it is implied that Uncle Philip has similar feelings towards his sister, Melanie's mother, which lurks in the wedding photo and his birthday present to Melanie. The performance, in a way, symbolises her entrance into the patriarchal order with the erasure of her subjectivity. The double-perspective of the narration and focalisation from a feminine point of view inverts the expectations about the father's disciplining role:

She was hallucinated; she felt herself not herself, wrenched from her personality, watching whole fantasy from another place; and, in this staged fantasy, anything was possible... The swan made a lumpish jump forward and settled on her loins. She thrust with all her force to get rid of it but the wings came down all around her like a tent and its head fell forward and nestled in her neck.... She was covered completely by the swan but for her kicking feet and her screaming face. The obscene swan had mounted her. She screamed again. (MT 2006: 166-7)

Angela Carter reverses the role of the father to discipline his daughter's desire for him with the incest taboo by conducting this scene with a female extradiegetic narrator. This violence is expected to protect her against the incestuous desire; however, Uncle Philip is portrayed as a primordial father who owns all women of the tribe: "Such a father punishes his daughter and takes pleasure from doing so" (Pyrhönen 2007: 105). Melanie's acting creates real fear in her, which makes Uncle Philip angry because she overreacts. Philip cuffs 
her with the back of his hand and rebukes her for being "melodramatic": "puppets don't overreact. You spoiled the poetry" (MT 2006: 167). After the Leda and Swan show, Melanie is positioned as castrated, passive and an object of man's desire rather than a subject who holds on to her desires. In other words, she speaks "in a mode of masquerade, in imitation of the masculine, the phallic subject" (Grosz 1990: 71). Apart from its incestuous overtones, Uncle Philip's virtual rape alludes to how the symbolic father becomes an ideal embodiment of patriarchal law. The rest of the family must join in this act of submission to the Law: Francis by playing the violin, Finn managing the stage lights and Aunt Margaret clapping her hands (MT 2006: 167-8).

In "The Signification of the Phallus," Lacan interrogates the link between killing the father and "the pact of the primordial law" whereby the castration is offered as a penalty for incest (576). In his reformulation of the Oedipal dynamic, Lacan makes use of the paternal metaphor in terms of the child's submission to the name-ofthe-father. The prohibition of incest and establishment of paternal authority shows how the child is submitted to the paternal metaphor. The child can "accede to the paternal metaphor by means of acknowledging castration and privation" (Grosz 1990: 104). The first puppet show stages Finn's symbolic castration which he denies until the chopping of the swan. He is left motionless for a while after the show; he is lying on the floor "broken like a toy" under the "terrible sound of Aunt Margaret's silence" (MT 2006: 132). Following the puppet show, he falls from grace and turns into a different man:

After he fell, he changed .... He rarely spoke. His stream of talk was dried up at the source ... He grew dirtier than ever. Worst of all his grace is gone. Miraculously, the fall left him whole, with no injury internal or external, but it had shaken the beauty out of his movements. He stumped like an old man ... He ignored her; not, it seemed on purpose, but because only Uncle Philip was real to him any more. (MT 2006: 134)

With the entrance of the paternal metaphor, Finn substitutes his desire for the (M)Other — both Melanie and Aunt Margaret — with the Law of the father. He acknowledges his castration after he chops up the 
swan with "Maggie's axe" in the pleasure garden; he "kill[s] his swan for him" (MT 2006: 174). The totemic father re-establishes himself as the figure of absolute power in the puppet-shows, taking "the women and wealth of the primal horde by expelling his sons and rivals," in other words, Uncle Philip prohibits Finn the access of the women of the horde (Homer 2005: 59). Like Melanie, who is transformed from an active girl to an object by the Law, Finn's sexuality is accorded with his gender role. In these two puppet shows, the Oedipal socialization of Melanie and Finn is staged, rendering them objects of the patriarchal social order.

The primordial father in Freud's Totem and Taboo remains outside the law of castration. There is also no incest prohibition for him; all women belong to him. Identification with the primordial father may produce unlawful desires like that of Finn and Francie, one of which is incest and the other is the wish to kill the father (Freud 2004: 153). While the paternal law perpetuates the prohibitions of incest, this authority is continuously challenged by Margaret and Francie. Margaret and Francie reject entering the chain of signifiers. Finn is an accomplice as he shares this secret, taking pleasure from Francie's cuckolding the totemic father and considering the incest as "the thing that makes [them] different from other people" (MT 2006: 195). The 'red people,' in a way, construct their own subjective realm with extra-linguistic activities such as music-making, dancing and painting.

For Lacan, if the child is still attached to its double, s/he cannot acquire a social space outside the familial orientation. In order to participate into larger linguistic and social community, the child must be disconnected from its imaginary identifications. This is important in Lacan's understanding of acquiring social identity and becoming a speaking subject. For this reason, Margaret, Francie and Finn have difficulty in adopting a position within the culture they live in; instead, they establish ex-centric identities in their subjective realm. Especially Margaret and Francie's relationship suggests the formation of an enclosed and mutually dependent relationship. Despite Uncle Philip's authority which presides all over the place, the narcissistic couple secretly disregard the Symbolic regulation. Having a sexual affair with 
the $\mathrm{m}(\mathrm{O})$ ther, Francie violates what is forbidden to him. Uncle Philip does not fulfil his function to normalise the child's demands and his desire for the mother by prohibiting sexual access to her. Francie cannot acquire a position from which to speak or from where the signifier "I" will establish him as the subject (Homer 2005: 57). His connection with the mother prevents him from developing a sense of self. Aunt Margaret, who is "inscribed as post-Oedipal" and normatively an adult subject, displays "the problematical relation of subjectivity to the gaze within the dynamics of the Imaginary and the Symbolic" (Mellard 1991: 70). The mother/child dyad is used as a place for the conduct and subversion of patriarchal values, avowing the repressed but simultaneously preserved "archaic force of the preoedipal." This affirms "the fluid, polymorphous perverse status of libidinal drives" and induces "a series of sites of bodily pleasure capable of resisting the demands of the symbolic order" (Grosz 1990: 149).

With the internalisation of the Symbolic father's authority, the mother/son dyad is shattered and the desire of the son is repressed. However, the incestuous relationship between Aunt Margaret and Francie shows that they do not accept the Law, its symbols of authority; they inevitably oscillate between two registers. When compared to them, Finn seems to have accepted the Law of the father. However, after the Leda and Swan show he rebels in his own way, symbolically killing the father figure by beheading the Swan:

'...He must be off his head.'

'But why did you break up the swan?'

'I was lying in my bed and suddenly I thought I'd do it. I don't know why. It came to me, I'll kill his swan for him.'

'He'll murder you,' she said....' Of course, he wants me to say that'

'We'll put the cards on the table, me and him' (MT 2006: 172).

After Finn chops the swan's head as an act of rebellion, he replaces the 'father' and becomes the new advocate of social order in the toyshop. In other words, by killing the father the subject takes the father's place. The symbolic death of the 'Father' is inspired by the desire for the mother. Therefore, Finn's castration process is as problematic as that of Francie's. He cannot completely suppress his 
desire or accept the social order represented by Uncle Philip; he keeps up his "ontological struggle" with him (Homer 2005: 59). The next morning, the household wakes up and discovers Uncle Philip's absence from his gone false teeth, "a white hair in the crack in the basin" and the damp towel (MT 2006: 181). His absence is replaced by Finn, who takes his place on "the Siege Perilous," Uncle Philip's ominous chair. He sits at the head of the table "like the Lord of Misrule" and it becomes "quite normal for Finn to be seated there" and Victoria identifies him as "Daddy" (MT 2006: 183). Finn owns all the objects that signify the Law: Uncle Philip's mug with rosebud lettering 'Father', a clean shirt, the cuckoo clock and the dog (MT 2006: 185-6). They wear their best and cleanest clothes and Francie and Aunt Margaret begin to play "jigs and reels." Francie asks Finn to dance; Finn refuses saying "[m]y dancing days are over...I'm almost a family man, now" (MT 2006: 191). Finn's identification with the primal father involves an "ambiguous process whereby the subject simultaneously identifies with authority, the law" and with the "illicit desires that would transgress and undermine the law" (Homer 2005: 59).

Unlike Uncle Philip's workshop and theatre-stage, the kitchen becomes a space for the Jowle rebellion. They decide not to open the toyshop and stay in the kitchen which is transformed into a party place where they drink, play music and laugh. Finn subverts Philip's order by flinging the mug at the cuckoo-clock and the stuffed cuckoo "belted out thirty-one calls and then jerked back into the clock...The ticking stopped" (MT 2006: 185). Aunt Margaret wears Melanie's dress and the pearls, Melanie puts on her trousers and Victoria leaps around the kitchen "from lap to lap" (MT 2006: 191). They soon discover that it is "far nicer without Uncle Philip" (MT 2006: 192). The entire day is devoted to a renunciation of Uncle Philip, namely, the renunciation of the Law. Francie and Margaret, with the ecstasy of the moment, embrace which "annihilat[es] the world" (MT 2006: 193). Melanie, aware of the prohibitions of incest, is surprised to see Margaret and Francie like "the Kings and Queens of Ancient Egypt." Even the dog and his portrait "gazed at them uncensoriously" (MT 
2006: 194). Identifying himself with the primal father, Finn does not prohibit the act of incest, but Melanie cannot consent to this unlawful act easily, "I have never encountered it before...Not incest, not in my family" (MT 2006: 194). The very familiarity of the kitchen makes it an attractive place for enacting subversive behaviour with the eruptions of the repressed desire. Along with the final scene, Melanie's voyeurism through the keyhole and her hallucinations of the bloody hand also show how the kitchen turns into a potential space for sexuality, passion, violence and destruction. Aunt Margaret, as the desexualized (surrogate) mother, revitalises her sexuality with an unlawful sex in the kitchen, a place which mothers are usually associated with. This act disrupts all the social perceptions of womanhood and motherhood.

By way of conclusion, Angela Carter achieves a subversive potential for the inscription of female subjectivities in The Magic Toyshop by rewriting the patriarchal myths and questioning the cultural codes about sexual behaviour. Melanie is first overtaken with the narcissistic desire, appropriating herself to the male gaze. After moving into Uncle Philip's house, she learns to suppress her desire and avoid Philip's wrath with the help of Finn and Margaret, who help her to 'read' the codes of the toyshop. The paternal metaphor, however, fails to interfere with the narcissistic and incestuous structures of identifications in the mother/son dyad between Margaret and Francie. Upon discovering Margaret and Francie's incestuous relationship, Uncle Philip sets the house on fire, which can be seen as "patriarchy's self-inflicted destruction" (Gamble 1997: 73). The end of the novel resembles the biblical story of Adam and Eve; after the fire in Philip's house - the murder of the primordial (F)Other, the only survivors are Melanie and Finn. Carter depicts the two in a world where a new beginning is possible even though there are no structures. However, the two are somehow banished from the Father's house, like Adam and Eve - since they fall too short to conform to the Symbolic order. 


\section{Works Cited}

Carter, A. (2006): The Magic Toyshop. London: Virago.

Freud, S. (2004): Totem and Taboo: Some Points of Agreement between the Mental Lives of Savages and Neurotics. London and New York: Routledge.

Gamble, S. (1997): Angela Carter Writing from the Front Line. Edinburgh: Edinburgh University Press.

Grosz, E. (1990): Jacques Lacan: A Feminist Introduction. London and New York: Routledge.

Homer, S. (2005): Jacques Lacan. New York and London: Routledge.

Lacan, J. (2006): Écrits. Trans. Bruce Fink. New York and London: W. W. Norton and Company.

Mellard, J. M. (1991): Using Lacan, Reading Fiction. Urbana: University of Illinois Press.

Pyrhönen, H. (2007): Imagining the impossible: The erotic poetics of Angela Carter's 'bluebird' stories. Textual Practice 21.1: 93-111.

Sarup, M. (1992): Modern Cultural Theorists: Jacques Lacan. Hemel Hempstead: Wheatsheaf. 